\title{
Legal Remedies for Marine Ecological Damage in China: As Illustrated by the Tasman Sea Oil Spills Case
}

Xiaoqin Zhu* Lin Dong **

This paper analyzes legal remedies for marine ecological damage as provided in Article 90, Section 2 of the Marine Environment Protection Law of the People's Republic of China. In doing so, the paper examines the Tasman Sea Oil Spills Case, the first civil case in China to claim marine ecological damage involving foreign interests. The paper finds that many issues arise in practice due to the simplicity of the relevant legal provisions. The existing international treaties on marine oil pollution damage caused by ships do not cover marine ecological damage. However, domestic courts of some countries have relevant judicial practice on the matter. Hence, it is urgent to establish a set of new rules on marine ecological damage compensation in China and to specify the claimants, the scope for compensation and the measure of indemnity with the aim of providing an effective legal remedy for marine ecological damage.

\section{Keywords}

Tasman Sea Case, Marine Ecological Damage, Legal Remedy, Tianjin Maritime Court

\section{Introduction}

China' s rapid economic development is the key to increasing number of activities to production output including marine transportation, oil exploration and exploitation, and marine fishery production. This has resulted in an increased risk of significant

\footnotetext{
* Professor of international law at the School of Law of Xiamen University, China. Ph.D(Xiamen). The author may be contacted at: xqinz98@gmail.com/Address: School of Law, Xiamen University, 361005, Fujian Province, China.

** Ph.D. Candidate at the School of Oceanography and Environment, Xiamen Universtiy.
} 
accidental oil spills from ships. Additionally, with the rapidly growing consumption of oil, China has evolved into one of the largest importers of petroleum in recent years. In 2007, China imported nearly 200 million tons of petroleum. ${ }^{1}$ This enormous scale of petroleum import takes place mainly through ships entering through China such that the probability of oil spills occuring in China's sea areas has and will continue to significantly increase. ${ }^{2}$ According to annual bulletins published by the Ministry of Environmental Protection on the environmental quality of China' s offshore areas, there were 124 pollution accidents caused by ships along China's seaboard in 2006 and 107 similiar accidents in 2007. The total volume of oil leakage in 2006 was 1,216 tons including 5 accidents involving oil and chemical pollution with oil leakage volumes of more than 50 tons. In 2007, the total volume of oil leakage was nearly 900 tons, with 38 oil spills of more than 0.1 tons each and 5 oil spills with a volume of oil leakage of more than 50 tons. ${ }^{3}$ These frequent oil spills make the already worrying state of the ecological environment in China' s seas even worse.

\section{Definition of Marine Ecological Damage}

Scholars have not yet succeeded in reaching a consensus on a uniform definition of the term "ecological damage." Nonetheless, there are a number of scholars attempting to give the term an academic definition. For example, Dr. Lahnstein Christian has argued that "ecological damage is material damage to nature, specifically to earth, water, air, climate, landscape, flora and the fauna living in them, and to the interaction between them. It is also conspicuous man-made damage to the ecosystem and its component parts." 4

According to academic jargon used by legislators and scholars, both in China and elsewhere, "ecological damage," "pure ecological damage," "damage to the environment per se," "environmental damage," "pure environmental damage," "impairment of the environment" and "natural resource damage" are often used without significant

1 Available at http://www.china.com.cn/economic/txt/2008-03/03/content_11402622_2.htm (last visited on Aug. 15, 2009).

2 ZHU Zhenyu \& ZHANG Hongyu, Preventive Measures for the Oil Spill Accident of Ships, 22 Petrochemical SAFETy TECHNOLOGY (2006).

3 Ministry of Environmental Protection(P.R.China), Bulletin on the Environmental Quality of China's Offshore Areas In 2006; Bulletin on the Environmental Quality of China's Offshore Areas in 2007, available at http://www.mep.gov.cn/tech/hjjc/jcxx/jagb/(last visited on July 10, 2009).

4 Lahnstein Christian, A Market-Based Analysis of Financial Insurance Issues of Environmental Liability Taking 
differentiation. 5 "Ecological damage" is frequently used by European scholars, ${ }^{6}$ while "natural resource damage" is the term often used in U.S. law and by American scholars. For example, the U.S. Oil Pollution Act of 1990 ( "OPA")7 in Section 1002 (b)(2)(A) defines "natural resource damage" as "damages for injury to, destruction of, loss of, or loss of use of, natural resources, including the reasonable costs of assessing the damage."

The terms "pure ecological damage," "pure environmental damage" and "environmental damage" are usually used to refer to damage to the environment per se. Since environmental elements do not belong to any individual, after being defined as "pure" these damages do not include personal injury to victims or property damage. 8

The term "marine environment" includes sea water, substances both dissolved and suspended in sea water, sediment and living organisms in the ocean. According to Article 95, Section 1 of the Marine Environment Protection Law of the People' s Republic of China ("MEPL"),9 "pollution damage to the marine environment" means any direct or indirect introduction of substances or energy into the marine environment which results in deleterious effects such as harm to marine living resources, hazards to human health, hindrance to fishing and other legitimate activities at sea, impairment of the useful quality of sea water and degradation of environmental quality. The authors believe that "harm to marine living resources," "impairment of the useful quality of sea water" and "degradation of environmental quality" are specific damages to marine ecology.

Special Account of Germany, Austria, Italy and Spain, in Deterrence, Insurability, and Compensation in Environmental Liability: Future Developments in the European Union, 307 (Faure Michael ed., 2003).

5 ZHU Xiao, A Reflection on the Legal Awkwardness of the Administrative Fine in the Songhua River Pollution Accident-from the Point of Liability for Ecologic Damages, 3 The LEgAl Science Monthly (2007).

6 M.C. Maffei, The Compensation for Ecological Damage in the "Patmos"Case, in InTERnATIONAL ResPonsiBILITY FoR Environmental Harm 381(F. Francioni and T. Scovazzi eds., 1991).

7 Oil Pollution Act of 1990, Public Law 101-380 (As amended through P.L. 106?580, Dec. 29, 2000), 33 U.S.C. 2701 et seq.; 104 Stat. 484.

8 Brans Edward, Liability for Damage to Public Natural Resources: Standing, Damage and Damage Assessment, NETHERLANDS 20 (2001).

9 Adopted at the 24th Meeting of the Standing Committee of the $5^{\text {th }}$ National People's Congress on August 23, 1982; revised at the 13th Meeting of the Standing Committee of the $9^{\text {th }}$ National People's Congress on December 25, 1999 and promulgated by Order No. 26 of the President of the People's Republic of China on December 25, 1999. 


\section{Practical Confusion caused by Excessive Simplicity of Legislation}

China has already established legal remedies for marine ecological damage. According to Article 90, Section 2 of the MEPL:

[F]or damages to marine ecosystems, marine fishery resources and marine protected areas which cause heavy losses to the State, the department invested with power by the provisions of this law to conduct marine environment supervision and administration shall, on behalf of the State, put forward compensation demand to those held responsible for the damages.

However, this provision is too simple to work well in practice with the result of a large amount of practical confusion.

The Tasman Sea Case illustrates this point. The Tasman Sea, a Maltese tanker carrying 80,000 tons of crude oil, collided with a Chinese ship, the Shunkai No.1, in Bohai Bay on November 23, 2002. This accident caused a crude oil leakage of about 200 tons resulting in heavy environmental pollution in the Bohai Sea areas and posed a huge threat to the marine ecological environment. The event led to an oil pollution compensation lawsuit which lasted for two years and involved 10 cases including more than 1,500 plaintiffs and 170 million RMB.10 It was the first claim against the insurers of foreign companies based on the International Convention on Civil Liability for Oil Pollution Damage( "CLC") 11 since China joined this Convention. It was also the first civil case of a legal nature lodged by China's Oceanic Administrative Authority to claim marine ecological damages involving foreign interests. The case created a national precedent to preserve the rights and interests of the Chinese government regarding the marine ecology environment and, hence, attracted widespread media attention at the time.

After several trials, on December 30, 2004, two years after the accident, the Tianjin Maritime Court of China made the first trial judgment on the 10 cases related to the event.12 The defendants, the owner of Tasman Sea and the London Steam-Ship Owners Mutual Insurance Association LTD., were held jointly and severally liable for the plaintiff's compensation to the Tianjin Oceanic Administration of nearly 10 million RMB (7.5 million RMB for the loss of marine environmental capacity and 2.5 million RMB for the cost of investigation, monitoring, evaluation and bio-restoration research).

\footnotetext{
10 Available at http://www.022net.com/2008/2-27/454024372361491.html (last visited on July 15, 2009).

11 U.N.T.S. A-14097.

12 See Jin Haifa First Trial No. 183,184,185,186 Civil Verdict, Tianjin Maritime Court (2003).
} 
The defendants were also held liable to the plaintiff, the Tianjin Fisheries and Fishing Port Supervision and Administration Agency, for more than 15 million RMB for the loss of fishery resources as well as more than 17 million RMB in compensation for 1,490 fishermen for their losses and damages. The final amount of compensation in this claim was more than 42.09 million RMB.13 In the cases of Tianjin Oceanic Administration and Tianjin Fisheries and Fishing Port Supervision and Administration Agency, which dealt with the compensation for marine ecological damage, both the plaintiffs and the defendants did not accept the judgements of the lower court but also appealed to the Tianjin High Court. As of October 2009, those two cases are still ongoing and final judgements have not yet been reached.

Another example involved a Portuguese tanker in the Arteaga case. Fully loaded with crude oil, the Arteaga accidentally struck a rock formation while entering Dalian New Port on April 3, 2005. Due to the collision, the tanker began leaking huge amounts of crude oil, which resulted in heavy pollution to the marine environment. A total of 104 sea-water aquaculture enterprises and fishermen nearby were affected and the parties lodged a compensation lawsuit with a maximum claim of one billion RMB. In May 2009, after more than three years of hearings, the 104 sea-water aquaculture enterprises and fishermen reached reconciliation with the defendant. 14 However, the marine ecological damage compensation lawsuit initiated by the Dalian Oceanic and Fishery Administration on behalf of the State is still awaiting the judgement of the Dalian Maritime Court.15

The frequency of oil pollution incidents is currently increasing in China's sea areas. It indicates that each case has the volume of oil leakage above one ton.

However, only a few lawsuits have resulted from such incidents. These lawsuits have often become long, drawn-out and unresolved cases. This phenomenon fully exposes the problem of the Chinese legal systems for compensation related to marine ecological damage. On the surface, the point of contention between parties to such lawsuits is the assessment of the value of marine ecology. However, there are also problems related to evidentiary procedures in civil lawsuits regarding compensation for marine ecological damage. In fact, it shows that China's legal system related to compensation for marine ecological damage is not sound enough to carry out its purpose in practice. The problems, including the lack of relevant substantive law, such as the indeterminacy of the status of the litigant and the incompleteness of the measure of indemnity, lead to the severe consequence that nobody pays for marine ecological

13 The first Instance of the "Tasman Sea" Case, China OcEan NEws, Dec. 31, 2004, at 1.

14 Oil tanker leaked crude oil on the rocks, the first maritime case of claiming damages lasted 3 years, available at http://www.hilizi.com/2009-05/14/content_313031.htm (last visited on June 15, 2009).

$15 \quad I d$. 
damage. As a result, the Chinese marine ecosystem, which has been deteriorating, is thereby becoming even more fragile. Therefore, it is exremely urgent for China to improve its legal remedy systems against marine ecological damage.

\section{Applicable Laws}

\section{A. Relevant Conventions}

After years of practice and development, the relevant compensation system for marine ecological damage caused by oil spills and the provisions of the CLC and the International Convention on the Establishment of an International Fund for Compensation for Oil Pollution Damage have gone through several changes. In the beginning the conventions did not clearly take into account compensation for marine ecological damage caused by oil spills. Later, the conventions only stipulated that compensation for the reasonable expenses related to oil pollution removal, and environment restoration would be awarded with the principle of excluding damage to the environment per se.16 A renowned international environmental law scholar has commented that "whether the purpose of the international environmental protection conventions is to prevent or to reduce the damage to the environment per se, the purpose of most international conventions on civil liability is to build compensation liability for the damage of humans, their property and their economic status caused by the environmental damage, not to build compensation liability for environmental damage." 17

It is evident that the purpose of the CLC,18 the International Convention on the Establishment of an International Fund for Compensation for Oil Pollution Damage,19 and the series of related protocols, is only to provide legal remedies for personal injury or property damage caused by oil spills. This kind of civil liability pursues the principle of compensation and limitation of liability. Limited by the initial design, these conventions have not taken into account compensation for ecological or environmental damage. There are no provisions applicable to legal remedies for ecological damage,

\footnotetext{
16 ZHU Xiao, On Ecological Compensation under the Framework of "International Convention on Civil Liability for Oil Pollution Damage" and "International Convention on the Establishment of an International Fund for Compensation for Oil pollution Damage," Political ScIENCE AND Law (2006).

17 De La Fayette, Louise, The Concept of Environmental Damage in International Liability Regimes in Environmental Damage in International and Comparative LaW 156 (2002).

18 U.N.T.S. A-14097.

19 U.N.T.S. I-17146.
} 
e.g., compensation for ecological damage does not apply the principle of limitation of liability. That point has been embodied in the Provisions of China's Supreme People's Court on Some Issues about the Trial of the Cases of Ship Collision Disputes, ${ }^{20}$ which have come into force since May 2008.21 It can be said that there are at present no effective and applicable international treaties related to compensation for marine ecological damage caused by oil spills. If one wants to find effective legal remedies for marine ecological damage caused by oil spills, the only solution is to turn to relevant provisions of Chinese domestic law.

\section{B. Relevant Domestic Judicial Practices}

There have been some cases in certain countries, such as the Patmos Case (Italy)22 in 1985 and the Haven Case (Italy) 23 in 1991, in which domestic courts have recognized that marine environmental damage could be an ndependent compensable item and that compensation for marine environmental damage included quantifiable and unquantifiable factors.

In the Patmos Case, the Italian Maritime Administration made an appeal based on compensation for marine environmental damage. The Italian Court of Appeals of Messina supported the appeal request in 1989. Referring to a previous decision made by the Italian Constitutional Court in 1987 (No. 641 Authoritative Judgment), the Messina Court of Appeals affirmed the reasonable compensation judgement of the lower court for environmental damage stating that: "the public had suffered the pain of the loss of enjoyment" of which the appellant was the Italian government as the trustee of the national heritage. 24 One scholar has commented that the Italian Court of Appeals set an important precedent in the judgment of the Patmos litigation ${ }^{25}$ which confirmed that ecological damage could be eligible for compensation under the framework of the

20 Judicial Interpretation No. 7 [2008], passed by the $1446^{\text {th }}$ conference of the Judicial Committee of the Supreme People's Court on April 28, 2008.

21 E.g., Article 9 of this provision says: In case compensation is required for the expense of refloating, removing and demolishing the sunken, wrecked, aground or abandoned ship and cargo on board or making it harmless, the obligors shall not be entitled to the benefit of limitation of liability for maritime claims provided in Chapter XI of China's Maritime Law.

22 Italian Maritime Ministry v. Patmos, sued in 1985 and appealed in 1989.

23 Italian Government, etc. v. Haven, sued in 1991.

24 The Italian Constitutional Court Judgment No.641 (1987). The judgment also referred to Italian domestic law Article 18 of Act No. 349 of 1986. Act No. 349 of 8 July 1986, Istituzione del Ministero dell' ambiente e norme in materia di danno ambientale, in [1986] 162 Gazzetta Ufficiale, Suppl. Ord. No.59, 5 ff. See ZHU Xiao, On Ecological Compensation Under the Framework of "International Convention on Civil Liability for Oil Pollution Damage" and "International Convention on the Establishment of an International Fund for Compensation for Oil Pollution Damage," Political SCIENCE AND LaW (2006).

25 Supra note 22 . 


\section{CLC. 26}

In another example, the Tasman Sea Case, the two defendants argued that the losses to environmental capacity and to the ecosystem service claimed by the plaintiffs neither existed, nor constituteed pollution damage recognized by the 1992 Protocol to the CLC. According to the protocol, even though the oil spill had caused marine ecosystem damage, the plaintiff could not receive compensation for the cost of environmental recovery; the cost of assessment and the marine ecosystem restoration claimed by the plaintiffs was untenable.

The Tianjin Maritime Court rejected the defendants' request to apply the International Oil Pollution Compensation Fund Claims Manual27 and the Com ité Marltine International ("CMI")Guidelines for Oil Pollution Damage. ${ }^{28}$ The Court considered China's domestic laws and applied them in the case.29 The Court held that Article 3 of the MEPL sets a rule for the "System of Controlling the Total Sea-Disposal Pollution Discharge for the Key Sea Areas." Since the Bohai Sea is a semi-enclosed bay, the time for the sea water's exchange is very long, which causes Bohai's self-purification capacity to be comparatively weak. According to the Action Plan for the Blue Bohai Sea ${ }^{30}$ and the 21st Century Agenda for China's Ocean, 31 the Bohai Sea near Tianjin City should be strictly controlled in the field of Total Sea-Disposal Pollution Discharge because the sea areas were polluted by the Tasman Sea's oil spills.

As for the light crude oil pollution involved in the case, no matter how large the polluted sea areas were, there is no doubt that the amount of light crude oil in the Bohai Bay increased due to the spill. This increase took up part of the quota of pollutants allowed to be discharged into this sea area and resulted in the loss of the Bohai Bay's environmental capacity to a certain degree.32 The Court also believed that although the oil pollutants remaining in the marine sediments of the sea area had reached the first class criteria after one year's degradation, the average oil content found in the sediment was still 0.68 times higher than before. Therefore, the sea area should be restored by taking appropriate measures.

Bianchi Andrea, Harm to the Environment in Italian Practice: The Interaction of International Law and Domestic Law, in P. Wetterstein, Harm to the Environment: The Right to Compensation and the Assessment of Damages 113-118 (1997).

27 Passed by the conference of International Fund for Compensation for Oil Pollution Damage in October, 2004.

28 Passed by the Comité Maritime International in 1994.

29 See Jin Haifa First Trial No. 183 Civil Verdict, Tianjin Maritime Court (2003).

30 Approved by Chinese State Coucil in 2001, from 2001 to 2015 available at http://www.zhb.gov.cn/plan/hjgh/bohai (last visited on July 19, 2009).

31 Published by Chinese State Oceanic Administration in 1996, available at http://www.soa.gov.cn/hyjww/zwgknew/ zcfg/webinfo/2008/05/1210062818425112.htm (last visited on July 19, 2009).

32 Supra note 29.
} 
After analyzing an enormous amount of data on marine eco-environment damage and its verification of the plaintiffs' corresponding loss, the Tianjin Maritime Court held at the first trial that the first defendant, Infinity Shipping CO. should compensate the plaintiff, Tianjin Oceanic Administration in the amount of 7.5 million RMB for the loss of marine environmental capacity and 2.5 million RMB for the cost of the investigation, monitoring, evaluation and bio-restoration research; moreover, the first defendant was required to make the interest payments of the above-mentioned losses. ${ }^{33}$ The second defendant, London Steam-Ship Owners' Mutual Insurance Association LTD., was found jointly liable. 34

If China wishes to effectively regulate the marine ecological damage caused by oil spills, in the absence of directly applicable international conventions, the relevant domestic law such as Article 90, Section 2 of the MEPL should be improved so that it would provide an effective legal remedy for marine ecological damage.

\section{Specifying Claimants}

\section{A. Individuals have No Rights to Claim Ecological Damages}

Article 90, Section 1 of the MEPL provides that:

[A]ny party that is directly responsible for pollution damage to the marine environment will be held liable for the damage and must compensate for the losses, and where the pollution damage to the marine environment is entirely caused by an intentional act or a fault of a third party, that third party must provide relief for the damage and will be liable for the compensation.

Meanwhile, Article 90, Section 2 of the MEPL provides that:

[F]or any damages caused to marine ecosystems, marine aquatic resources or marine protected areas that result in heavy losses to the State, the interested department empowered by the provisions of the MEPL must conduct marine environment supervision and control and must, on behalf of the State, claim compensation from those held responsible for the damages. 
According to the two sections of the MEPL, the liabilities might be different between damage caused by polluting the marine environment, and for losses caused by damaging the marine ecosystem. The damage caused by polluting the marine environment refers to infringement upon personal or property rights caused by the conduct of polluting the marine environment. It is a form of tort liability for enviornmental damage with its claimants being entitites or individuals whose interests are directly infringed upon. Meanwhile, for actions that cause marine ecological damage, such as damaging marine ecosystems, marine aquatic resources or marine protected areas, the purpose of related legal action are to protect the marine ecoenvironment. However, the marine eco-environment does not belong to any individual, but rather to the State. Therefore, tort liability of the marine ecosystem is different from traditional civil tort liability which deals with personal injury or property damage. Thus, the relevant State administrative agency has the right to claim marine ecological damages not as individuals but as representative of the national interest.

\section{B. Who has the Right to Claim Damages?}

According to Article 90, Section 2 the MEPL, only the administrative agencies that have the authority to supervise and manage the marine environment possess the right to claim marine ecological damages as a representative of the national interest. Pursuant to Article 5 of the MEPL, the administrative agencies that have the authority to supervise and manage the marine environment include the following: the administrative department of environment protection; the oceanic administrative department of marine affairs; the administrative department in charge of maritime affairs; and the administrative department of fisheries and the environmental protection department of the Armed Forces. However, due to the fact that all of the these departments have the authority to supervise and manage the marine environment, their authority overlaps, especially on some specific matters. In addition, when the ecological damage affects a number of adjacent areas, the relevant provisions are not clear in deciding which departments have the right to sue, which causes confusion in practice.

Due to the lack of clarity in the relevant provisions, scholars hold different views on which department has the right to claim marine ecological damages. For example, some scholars believe that when the oil spill of a commercial tanker occurs, it is generally the State Oceanic Administrative Department that has the right to claim marine ecological damages on behalf of national interest. 35 This lack of clarity brings uncertainty in

35 ZHAO Jinsong \& ZHAO Lujun, On the Issue of Litigants of Compensation for Ship Oil Pollution Damages, 1 ANNUAL of ChINA' s MARITIME LAW (2005). 
determining which department or departments have the right to claim marine ecological damages when a specific marine ecological damage case occurs. It will also sometimes lead to a lacunae since the State's right for claiming marine ecological damages would not exist if there was no department willing to bring such claims.

If the law is not clear as to who are the proper claimants, disputes over the issue of redundant claims can also easily arise in practice. For example, in the Tasman Sea Case, both defendants argued that the plaintiffs' claims were obviously repetitive,. After its examination, the Tianjin Maritime Court clearly announced the following: the Tianjin Oceanic Administration' s claim was the cost of marine environmental pollution, marine ecological damage and the measures to be taken for the corresponding ecological recovery; the fishermen from Luannan County of Hebei Province and Hangu, Beitang, Dagu of Tianjin City claims were the loss of fishing, loss of net ware and the death of beach shellfish aquaculture caused by the marine pollution; and the Tianjin Fisheries and Fishing Port Supervision and Administration Agency's claim was the loss of fishery resources. As a result, the parties' claims were clearly independent of each other in both scope and content. There was no duplication of claims. ${ }^{36}$ Although the Court ultimately found no duplication between the two claims, the Court did not elaborate on the reason for the judgment, which was one of the reasons why the defendants appealed.

The case also illustrates the confusion in judicial practice that is caused by the lack of clarity in Chinese legislation. One alternative to help ameliorate this confusion would be to adopt ideas from the U.S. Oil Polution Act of 1990. Under the OPA, damages for natural resources refer to:

[D]amages for injury to, destruction of, loss of, or loss of use of, natural resources, including the reasonable costs of assessing the damage, which shall be recoverable by a United States trustee, a State trustee, an Indian tribe trustee, or a foreign trustee. ${ }^{37}$

In other words, it is more feasible in practice to appoint a single administative agency to claim ecological damages on behalf of the national interest, while other relevant administrative agencies could provide assistance, especially technical support.

\section{Claiming Damages on behalf of the Public Interest}

In addition, the marine ecological damage compensation lawsuit lodged by the relevant administrative departments on behalf of the national interest is a special kind of civil lawsuit for the public interest, different from general civil cases. 38 Under such a civil law

36 See Jin Haifa First Trial No. 184 Civil Verdict, Tianjin Maritime Court (2003).

37 OPA, Section 1002 (b)(2)(A). 
structure, the relevant administrative departments, as a special party representing the national interest, should be different from the individuals in exercising procedural rights. For example, based on the dispositions maxim ${ }^{39}$ in the law of civil procedure, litigants have the right to decide whether to sue. When it comes to the relevant administrative departments that have an obligation to supervise and manage the marine environment, however, a claim for marine ecological damages is not only their right but their responsibility which cannot be forfeited. This means that damage claims are obligatory for the relevant administrative departments. It is obvious that the theory of dispositions maxim in civil procedure cannot be applied in such circumstances. Furthermore, the administrative departments lodging such a lawsuit are not property owners, so the following should be clearly defined in the law: whether the departments can pursue reconciliation on behalf of the national interest with the polluters in claiming marine ecological damages; whether the departments can relinquish some or all of the rights involved; and whether reconciliation between the departments lodging the lawsuit and the polluters should be approved by some other relevant department(s).

\section{The Scope of Compensation and the Standard of Indemnity}

\section{A. The Scope of Compensation}

There are limited provisions on the scope of compensation for marine ecological damages in Chinese laws. In this regard, the legislation and judicial practice of the United States may be used as a source of reference.

Although the United States is not party to any international conventions on ship oil pollution damage, the law of the United States contains provisions regarding the scope of compensation for oil pollution damage in the OPA. The scope of compensation for oil pollution damage provided in the OPA consists of two parts: the cost of removing the oil pollution and the cost of oil pollution damage. The oil pollution damages that can be claimed under the statute include the following: (1) damages for injury to, destruction of, loss of, or loss of use of, natural resources; (2) damages for injury to, or economic losses resulting from destruction of, real or personal property; (3) damages for loss of

38 Edward H.P. Brans, Liability for Damage to Public Natural Resources: Standing, Damage and Damage ASSESSMENT 17-18 (2001).

39 "Dispositions maxim" is a theory of procedural law in the continental legal system. It means that parties to a civil lawsuit have the initiative to decide whether or not to lodge an action or to abate an action. 
subsistence use of natural resources; (4) damages equal to the net loss of taxes, royalties, rents, fees, or net profit shares; (5) damages equal to the loss of profits or impairment of earning capacity; and (6) damages for net costs of providing increased or additional public services during or after removal activities. 40 These six areas embrace almost all conceivable potential losses including all costs of recovery, rehabilitation, alternatives, and restoration due to the destruction of natural resources; the loss of devaluation of the natural resource before its recovery; the reasonable cost of assessment, calculation and quantification of the damage. From the above, it is clear that compensation for ecological damage is naturally addressed under U.S. law.

In 1989, the EXXONVALDEZ, an American super tanker belonging to the EXXON Petroleum Company with deadweight of 215 thousand tons, crashed in Prince William Bay of Alaska causing 36 thousand tons of crude oil leakage, which polluted 1,609 $\mathrm{km}$ of the coast and $7,770 \mathrm{~km}^{2}$ of sea areas. 41 Based on the OPA, the American court held that EXXON should pay 8 billion dollars in penalties, cleaning costs, damages compensation (including ecological damage compensation) and other relevant costs.42

Referring to the OPA and the reports made by the relevant monitoring departments in the Tasman Sea Case, the scope of compensation for marine ecological damage, bascially respecting the relevant international conventions and regulations, should include the following four aspects. First, the cost of preventive measures is relevant. Preventive measures refer to any practical reasonable measures which are taken or will be taken in order to either prevent and curb ecological damage from happening and extending, or to minimize the degree of the damage to some within a minimum scope. For example, the terms "preventive measures" and "response cost" are referred to in Article 2(10) of Directive 2004/35/CE of the European Parliament and of the Council on Environmental Liability with Regard to the Prevention and Remedying of Environmental Damage as follows:43 "Preventive measures mean any measures taken in response to an event, act or omission that has created an imminent threat of environmental damage, with a view to preventing or minimizing that damage." Meanwhile, Section 302(7) of the United States Marine Protection, Research, and Sanctuaries Act of 197244 defines "response costs" as those actions taken or authorized by the Secretary to minimize destruction or loss of, or injury to, sanctuary resources, or to minimize the imminent risks of such destruction, loss, or injury, including costs related to seizure, forfeiture, storage, of disposal arising from liability under section

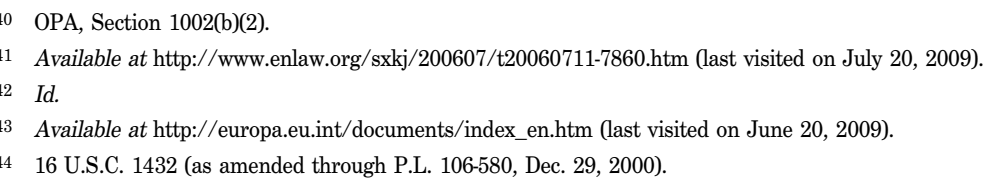


312."

Second, one must take into account the cost of removal measures. Once an oil spill occurs, one of the most basic and urgent problems is to clarify who has the responsibility of paying removal costs because in most cases it is not the obligor but the government that takes such removal measures. Examplary practices are noted in Italy, Belgium, the United States, the United Kindom, Sweden and many other coutries which have given compensation remedies to the removal cost or the clean-up cost to their respective legislative or judicial bodies. Examples can be found in Belgium's Decree Concerning the Prevention and Management of Waste Materials of 198145 and the relevant provisions of "After-treatment Liability to the Contaminated Lands and Waters" in Chapter 10 of the Swedish Environmental Code,46 the CLC, and the International Convention on the Establishment of an International Fund for Compensation for Oil pollution Damage.

Third, another important consideration is the cost of measures for ecological reinstatement. The specific measures for ecological reinstatement include the following: bio-reinstatement, botanical reinstatement, physical reinstatement, chemical reinstatement, eco-reinstatement etc. Section 8 of Article 2 of the Convention on Civil Liability for Damage Resulting from Activities Dangerous to the Environment ("Lugano Convention") 47 provides a clear definition of the "measures of reinstatement." The term refers to any reasonable measures aimed at reinstating or restoring damaged or destroyed components of the environment, or to introduce, where reasonable, the equivalent of these components into the environment.

The final important consideration relates to collateral damage. The issue of collateral damage concerns ecological damage assessment costs, monitoring costs, testing costs, research costs related to restoration measures and other administrative costs resulting from ecological damage. The Marine Protection, Research, and Sanctuaries Act of 1972 of the United States sets a good example in that scientific research costs as well as assessment costs are legally claimable. In the Act, Section 302(6) defines "damage" as to include "[...] (B) the cost of damage assessments under Section 312(b)(2); (C) the reasonable cost of monitoring appropriate to the injured, restored, or replaced resources;

"

45 Available at http://www.emis.vito.be/wet_ENG_navigator/AF.htm (last visited on Sept. 3, 2009).

46 Published by the Swedish Ministry of the Environment in August, 2000, available at http://www.sweden.gov.se/ $\mathrm{sb} / \mathrm{d} / 2023 / \mathrm{a} / 22847$ (last visited on Sept. 3, 2009).

47 Signed in Lugano, Switzerland, June 1993. Available at http://conventions.coe.int/Treaty/EN/Treaties/html/ 150.htm (last visited on June 30, 2009). 


\section{B. The Issue of Ecological Damage Assessment}

The focal point of intense controversy in the Tasman Sea Case was the assessment of the marine ecological value and the relevant damage. In the Tasman Sea Case, in order to clarify technical issues, with the consent of the plaintiffs and the defendants in the first trial, the Tianjin Maritime Court appointed the Shandong Maritime Judicial Expertise Center, as approved by the Supreme People's Court, to appraise the professional and technical issues involved in the case.48 From August to November 2004, the experts issued a series of reports, including the Assessment and Appraisal Report on the Cocontroversial Focal Facts in the Accident of "Tasman Sea" Ship's Oil Spills, the Assessment and Appraisal Report on the Fishery Resources Damage in the Sea Areas Polluted by "Tasman Sea" Ship's Oil Spills, the Assessment and Appraisal Report on the Ecological Damage and Restoration in the Accident of "Tasman Sea" Ship's Oil Spills etc. 49 The first trial court believed that the reports were based on an expert field survey together with a large amount of literature and offered a comprehensive analysis of the assessment reports submitted by the two parties. The conclusions of the report regarding the marine environmental situation before and after the accident were found to be in line with the reality. The reports were admitted by the Court. 50

However, the assessment of the value of the marine ecology and its damage is a very complicated and technical issue. As LI Bohua, the presiding judge of the Tasman Sea Case and head of the Tianjin Maritime Court said in media interviews, it is very difficult to quantify the extent of damage caused by the Tasman Sea's oil spills due to a lack of background environmental data regarding the Bohai Sea areas. This difficulty in quantification has a direct influence confirming the facts of the case. Moreover, the technology is not so advanced for taking evidence in the face of maritime accidents. This includes technology for determining the water coverage of the spot evidence, the choice of monitoring measures and the confirmation of technical standards. 51

Since there were no relevant authoritative technical specifications at the time, both parties held conflicting views leaving the court of first instance to address the amount of compensation for the marine ecological damage caused by Tasman Sea's oil spills, and both parties appealed to the higher court. Due to the complexity of this issue, it is likely that the two cases will not be resolved in foreseeable future.

Under current judicial practice, it is definitely not an easy task to confirm the extent of marine ecological damage caused by oil spills and the compensation amounts that the

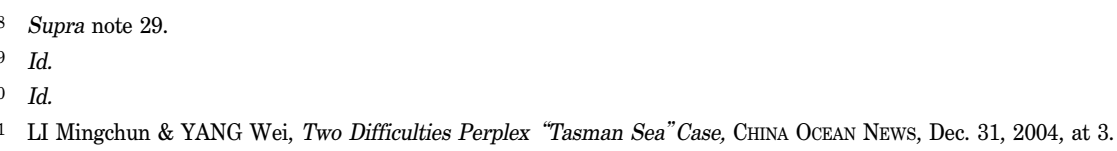


obligators should be responsible for without the necessary technological standards. However, there is no doubt that the marine ecological environment is the most direct victim in these marine oil pollution accidents. In order to meet the modern environmental protection requirements, it is also necessary to protect the marine ecological environment. It is predicted that China's sea areas would become the area which is likely to suffer from frequent accidents and is prone to accidental damages due to oil spills by ships. These oil spills are becoming increasingly harmful and impose a high risk to the coastal eco-environment. These problems should not be disregarded simply due to their complexity.52 On April 9, 2007, China's State Oceanic Administration officially released the Technical Guidelines on Ecological Damage Assessment of Marine Oil Spills. 53 It refers to the oil damage mechanism of the United States and clarifies the valuation of ecological damage in order to make it easier to follow. This Guideline is expected to provide an effective technical support for smoothly handling claims for marine ecological damage caused by oil spills. 54

\section{The Issue of the Standard of Indemnity}

Although Article 90, Section 2 of the MEPL does not set any standard of indemnity for marine ecological damage, but this issue can not be avoided in practice due not only to the value of marine ecology, but also to its damage which cannot be accurately quantified. At present, the only relevant provisions that can be invoked are the Rules on Calculation of Fishery Loss Caused by Water Pollution Accidents in 1996 ("the 1996 Rules").55 As an example, under Article 2 of the 1996 Rules, loss of natural fishery resources is calculated by the Local Fishery Supervision and Administration Agency in accordance with the local circumstances. Howver, the result should be at least three times as much as the direct loss of the aquatic product.

In the Tasman Sea Case, the CLC and its protocols do not provide specific provisions on how to calculate the damages and whether to compensate for the loss of natural fishery resources, as claimed by the Tianjin Fisheries and Fishing Port Supervision and Administration Agency. In this instance, the Tianjin Maritime Court held that the loss of natural fishery resources existed according to the monitoring data from Huang-Bohai

\footnotetext{
52 Tian Donglin, Ecological Damage by Marine Oil Spills Should Be Assessed Scientificly, China Ocean News, June 5, 2007 , at 2 .

53 Technical Guide for Assessment of Ecological Damage by Marine Oil Spills, HY/T095-2007, published by China's State Oceanic Administration, came into effect on May 1, 2007.

54 Tian Donglin, Ecological Damage by Marine Oil Spills Should Be Assessed Scientificly, China OcEan News, June 5, 2007 , at 2 .

55 Issued by the China's Ministry of Agriculture in 1996.
} 
Monitoring Center. Therefore, on the basis of confirming the loss under the 1996 Rules, the Court held in its first trial decision that the defendant, Infinity Shipping Co. should compensate the plaintiff, Tianjin Fisheries and Fishing Port Supervision and Administration Agency, 14.7 million RMB for the loss of fishery resources, 0.48 million RMB for the cost of investigation and assessment and that it should undertake the interest payments of these losses. The Court decided that the second defendant, London Steam-Ship Owners' Mutual Insurance Association LTD. should undertake joint liability. ${ }^{56}$ Certainly, as a final judgment in this case has not yet been rendered, whether the judgment made by lower court in accordance with such a simple standard of indemnity is correct remains an open question.

\section{Conclusion}

As marine ecological damage differs from traditional personal injury and property damage, there is no international conventions which are directly applicable to liability for compensation. However, if this gap is not filled and marine ecosystem damage is simply ignored, there would be no one to compensate for damage done to the marine ecosystem. Such a gap would certainly make the marine environmental situation in China even worse and seriously trample the maritime rights and interests of China. There already exists judicial precedent in some other countries to support claims for marine ecosystem damage in accordance with their domestic laws. In this regard, the following are urgent for China: to explore and construct a new legal system for compensation of marine ecological damage which is different from the ordinary environmental tortious system; to supplement and perfect related laws and further; and to provide an effective legal remedy for marine ecological damage on the basis of Article 90, Section 2 of the MEPL. 
